\title{
Rancang Bangun Hypobaric Storage sebagai Alat Penyimpanan Cabai Rawit (Capsicum frutescens $L$.)
}

\author{
Design of Hypobaric storage for Cayenne Pepper (Capsicum frutescens L.) \\ Dewi Maya Maharani ${ }^{1 *}$, Anang Lastriyanto, Vibi Rafiantoํ, Sonia Verent Yudi Santo Putri², \\ Kharimatul Khasanah ${ }^{2}$ \\ ${ }^{1}$ Jurusan Keteknikan Pertanian, ${ }^{2}$ Jurusan Teknologi Industri Pertanian, Fakultas Teknologi Pertanian, \\ Universitas Brawijaya, Jl. Veteran, Malang 65145, Indonesia \\ *Email: maya_maharahi@ub.ac.id
}

Tanggal submisi: 19 Juli 2018; Tanggal penerimaan: 14 Mei 2019

\begin{abstract}
ABSTRAK
Cabai rawit merupakan komoditas unggulan yang banyak dibutuhkan masyarakat Indonesia. Komoditas ini mudah mengalami kerusakan seperti susut bobot, turunnya kandungan vitamin C, warna memudar, dan pembusukkan sehingga menyebabkan umur simpannya berkurang. Proses penyimpanan yang tidak tepat menyumbang sekitar $30 \%$ kerusakan cabai rawit. Tujuan penelitian ini adalah merancang alat hypobaric storage yang dapat menurunkan tingkat respirasi produk hortikultura dan kadar gas etilen sehingga memperpanjang umur simpan cabai rawit. Alat ini terdiri dari beberapa komponen yaitu storage room, reservoir tank, vacuum pump, control penel, dan meja penyangga. Metode penelitian yang dilakukan adalah perancangan dan pengujian alat serta uji kualitas cabai. Hypobaric storage menggunakan tekanan -60 sampai $(-55) \mathrm{kPa}$ dan suhu $22,9{ }^{\circ} \mathrm{C}$. Hasil penelitian meliputi rancang bangun hypobaric storage, otomatisasi instrumen berjalan baik, dan cabai rawit yang disimpan dengan hypobaric storage memiliki susut bobot, kadar air, dan vitamin C sebesar 3,28\%; 1,05\%; dan 12,91\%. Perubahan parameter susut bobot, kadar air, dan vitamin C pada refrigerator adalah $6,66 \% ; 6,8 \%$; dan $48,61 \%$, sedangkan pada suhu ruang memiliki hasil 9,7\%; 15,98\%; dan 52,17\%. Hal ini menunjukkan bahwa Hypobaric storage for Chili mampu menjaga kualitas cabai rawit dibanding dengan penyimpanan suhu ruang dan refrigerator.
\end{abstract}

Kata kunci: Cabai rawit; hypobaric storage; rancang bangun penyimpanan, kualitas mutu

\begin{abstract}
Chili is a superior commodity that is much needed by Indonesian people. This commodity is susceptible to damages such as weight loss, decreased vitamin C content, color fades, and decay, which causes reduced shelf life. An improper storage process accounts for about 30\% damage to chili. The objective of the research was designing a chili storage tool based on the hypobaric system which can decrease the respiration rate and ethylene gas, thus expending the shelf life. This tool consisted of several components, namely storage room, reservoir tank, vacuum pump, control panel, and a table. The research method included design and instrument, also pepper quality testing. Hypobaric storage used a pressure of $-60(-55) \mathrm{kPa}$, and a temperature of $22.9^{\circ} \mathrm{C}$. The results showed that the hypobaric storage design, instrument automation ran well, and the chili with hypobaric storage had minimal weight loss, water content, and vitamin C degradation, at 3.28\%, 1.05\%, and $12.91 \%$. Parameters alteration based on entitlement with refrigerator were $6.66 \%, 6.8 \%$, and $48.61 \%$, whereas with room temperature the results were $9.7 \%, 15.98 \%$, and $52.17 \%$. Hypobaric storage for Chili was able to keep the chili quality better than room temperature and refrigerator.
\end{abstract}

Keywords: Cayenne pepper; hypobaric storage; storage design; quality stability

DOI: http://doi.org/10.22146/agritech.37230

ISSN 0216-0455 (Print), ISSN 2527-3825 (Online) 


\section{PENDAHULUAN}

Cabai rawit (Capsicum futescens L.) merupakan salah satu sayuran unggulan yang bernilai ekonomi tinggi. Cabai rawit adalah sayuran yang memiliki rasa pedas dan banyak digunakan sebagai bahan bumbu dapur, bahan utama industri saus, industri bubuk cabai, dan industri mie instan (Saraswati dkk., 2012). Produksi cabai rawit di Indonesia semakin meningkat. Pada tahun 2016 produksi cabai rawit mencapai 915.988 ton (BPS, 2017). Jumlah produksi tersebut diimbangi dengan tingkat konsumsi cabai yang mencapai 12.723 ton/ tahun (Survey Sosial Ekonomi Nasional, 2017). Namun faktanya Indonesia sering mengalami kelangkaan cabai rawit sehingga terjadi fluktuasi harga cabai rawit.

Kelangkaan dan fluktuasi harga cabai rawit disebabkan oleh adanya produksi/ panen, penyimpanan yang tidak efisien (Farid dan Subekti, 2012). Menurut Chitravathi dkk. (2016), kerusakan cabai rawit disebabkan oleh karakteristik cabai yang mudah mengalami kerusakan fisik dan pembusukan selama proses penyimpanan, karena memiliki metabolisme yang aktif dalam proses pematangan. Selama ini penyimpanan cabai rawit dilakukan dengan menggunakan ruangan terbuka sehingga cabai rawit cepat mengalami penurunan kadar air, perubahan warna, dan keriput dalam waktu singkat (Hameed dkk., 2015).

Teknologi penyimpanan cabai rawit yang sudah ada diantaranya penyimpanan pada ruangan terbuka, refrigerator, dan teknologi ozonisasi. Penyimpanan pada ruang terbuka tidak dapat membunuh mikroba pembusuk pada cabai, sehingga umur simpannya pendek yaitu sekitar 10 hari (Pradita, 2012). Penggunaan ruang pendingin dianjurkan untuk penyimpanan cabai karena dapat mempertahankan kesegaran produk untuk waktu yang lebih lama dibandingkan penyimpanan suhu ruang. Penyimpanan dengan suhu rendah $5{ }^{\circ} \mathrm{C}$ dapat mencapai 14 hari (Arifin, 2010). Setelah penyimpanan dengan refrigerator timbul gejala chilling injury yang meliputi lubang pada cabai, tekstur yang lembek, perubahan warna, dan kebusukan (Cantwel, 2009). Proses penyimpanan cabai dengan menggunakan ozonisasi dapat menghilangkan kontaminan pada cabai serta buah dan sayur lainnya tanpa menghilangkan warna, aroma, dan tidak mengurai senyawa organik yang terkandung dalam bahan pangan sehingga mampu memperpanjang umur simpan kesegaran hingga 8 hari. Perlakuan larutan ozon yang digunakan adalah 0.4 ppm menghasilkan susut bobot sebesar $15.5 \%$ dan kadar air cabai $85.53 \%$ yang terdapat pada cabai dan kesegaran warna dapat terjaga (Asgar dkk., 2017). Namun, ozonisasi berbahaya apabila ozon terhirup. Teknologi penyimpanan cabai dengan sistem hipobarik menjadi solusi dari permasalahan tersebut. Hypobaric storage menggunakan tekanan vakum dalam penyimpanannya sehingga dapat menurunkan tingkat respirasi produk hortikultura dan menurunkan kadar gas etilen agar dapat mempertahankan umur simpan.

Menurut Zapotoczy dan Markowski (2014), timun dapat disimpan hingga 30 hari dengan tekanan $10 \mathrm{kPa}$. Timun yang disimpan dengan hypobaric mengalami perubahan kecil pada jumlah komponen serat, pektin, dan gula dibanding penyimpanan suhu ruang. Menurut Chen dkk. (2013), penelitian perlakuan hypobaric dilakukan pada tunas bambu yang disimpan pada suhu $2{ }^{\circ} \mathrm{C}$ dengan tekanan $50 \mathrm{kPa}$ selama 35 hari yang hasilnya produksi etilen berkurang dan mampu menghambat pelunakan tekstur. Selain itu sistem hypobaric juga dapat mempertahankan tekstur yang dilihat dari penelitian sebelumnya pada komoditas strawberi bahwa bercak yang ditimbulkan akibat pengkerutan lebih sedikit ketika menggunaka hypobaric storage pada tekanan 25,3-50 kPa. Sedangkan untuk buah bayberi yang dilakukan pengujian dengan tekanan $55 \mathrm{kPa}$ menunjukan hasil bahwa warna pada buah bayberi yang disimpan menggunakan hypobaric storage lebih terjaga dan tidak terlihat menjadi lebih gelap selama penyimpanan. Kemudian, proses pematangan menjadi lebih lambat dan umur simpan sayur dan buah lebih lama (Thompson, 2016). Sistem hipobarik menggunakan perlakuan pemberian tekanan dibawah tekanan atmosfer untuk mengurangi ketersediaan oksigen dalam ruangan atmosfer terkontrol. Perlakuan diberikan dengan menggunakan tekanan -60- (-55) $\mathrm{kPa}$ dan suhu $22,9^{\circ} \mathrm{C}$. Teknologi ini dapat diaplikasikan sebagai alat penunjang distribusi cabai rawit yaitu dengan mengintegrasikan pada kendaraan distribusi. Keunggulan hypobaric storage dibanding penyimpanan dengan refrigerator dan ozonisasi dapat dilihat pada Tabel 1. Tujuan dari penelitian rancang bangun alat hypobaric storage antara lain merancang dan membuat hypobaric storage yang sesuai sehingga menjadi alat yang mampu memperpanjang umur simpan cabai rawit, menerapkan mekanisme kerja hypobaric storage sebagai alat yang mampu memperpanjang umur simpan cabai rawit, dan mengetahui hasil pengujian dan tingkat keberhasilan hypobaric storage dalam memperpanjang umur simpan cabai rawit. 
Tabel 1. Perbandingan Teknologi yang sudah ada

\begin{tabular}{|c|c|c|c|c|}
\hline \multirow[b]{2}{*}{ Parameter } & \multicolumn{4}{|c|}{ Jenis penyimpanan } \\
\hline & $\begin{array}{l}\text { Ruang terbuka } \\
\text { (Pradita, 2012). }\end{array}$ & $\begin{array}{l}\text { Refrigerator (Umam, } \\
\text { 2017) }\end{array}$ & $\begin{array}{l}\text { Ozonisasi } \\
\text { (Asgar dkk., 2015) }\end{array}$ & Hypobaric storage \\
\hline Perlakuan & $\begin{array}{l}\text { Diletakkan dalam box } \\
\text { kayu terbuka dan tidak } \\
\text { dilakukan pengemasan } \\
\text { sebelumnya }\end{array}$ & $\begin{array}{l}\text { Mengunakan suhu } \\
5^{\circ} \mathrm{C}\end{array}$ & $\begin{array}{l}\text { Menggunakan suhu } \\
10^{\circ} \mathrm{C} \text { dan konsentrasi } \\
\text { ozon1 ppm }\end{array}$ & $\begin{array}{l}\text { Menggunakan suhu } \\
22,9^{\circ} \mathrm{C} \text { dan tekanan } \\
(-60-(-55) \mathrm{kPa}\end{array}$ \\
\hline Umur simpan & 10 hari & $14-30$ hari & 32-38 hari & $40-45$ hari \\
\hline $\begin{array}{l}\text { Reaksi terhadap } \\
\text { kontaminan }\end{array}$ & $\begin{array}{l}\text { Tidak dapat membunuh } \\
\text { bakteri Altenaria dan } \\
\text { Brotytis }\end{array}$ & $\begin{array}{l}\text { Tidak dapat } \\
\text { membunuh bakteri } \\
\text { Altenaria dan } \\
\text { Brotytis }\end{array}$ & $\begin{array}{l}\text { Dapat mengurangi } \\
\text { bakteri Altenaria dan } \\
\text { Brotytis }\end{array}$ & $\begin{array}{l}\text { Dapat mengurangi } \\
\text { pertumbuhan bakteri } \\
\text { Altenaria dan Brotytis }\end{array}$ \\
\hline $\begin{array}{l}\text { Energi yang } \\
\text { dibutuhkan }\end{array}$ & - & 100-120 watt & $17.000-20.000$ watt & 360 watt \\
\hline $\begin{array}{l}\text { Kemudahan } \\
\text { distribusi }\end{array}$ & $\begin{array}{l}\text { Mudah namun } \\
\text { meningkatkan penurunan } \\
\text { kualitas }\end{array}$ & $\begin{array}{l}\text { Tidak dapat } \\
\text { digunakan untuk } \\
\text { proses distribusi }\end{array}$ & $\begin{array}{l}\text { Tidak dapat } \\
\text { digunakan untuk } \\
\text { proses distribusi }\end{array}$ & $\begin{array}{l}\text { Mudah karena } \\
\text { fleksibel dan mampu } \\
\text { menjaga kualitas }\end{array}$ \\
\hline
\end{tabular}

\section{METODE PENELITIAN}

\section{Waktu dan Tempat}

Kegiatan ini dilaksanakan selama 5 bulan dari bulan April-Agustus 2018. Pembuatan mesin dan pengujian dilakukan di Lastrindo Engineering, Laboratorium Bioindustri, serta Laboratorium Mutu dan Keamanan Pangan Universitas Brawijaya.

\section{Alat dan Bahan}

Alat yang digunakan untuk penyelesaian hypobaric storage adalah laptop untuk pembuatan desain, bor tangan untuk memberi lubang baut, obeng dan kunci untuk membuka dan merekatkan, solder untuk membuat rangkaian kabel, gerinda untuk menghaluskan sambungan, mesin las untuk menyambung bagian, gunting kabel untuk memotong perkabelan, avo meter untuk mengukur tegangan dan arus, meteran untuk mengukur dimensi. Bahan yang digunakan adalah toples kaca sebagai storage room, tabung acrylic sebagai tabung humidifier, plat besi sebagai bahan rangka, mur, dan baut sebagai penghubung komponen, kran $1 / 4$ inch sebagai pengatur keluar masuknya udara, selang pneumatic sebagai media penghubung vacuum pump dengan reservoir tank dan storage room, thermo couple sebagai sensor pendeteksi suhu, vacuum pump sebagai alat untuk membuat tekanan vacuum, reservoir tank sebagai tangki cadangan tekanan vacuum.

\section{Perancangan Alat}

Perancangan ini bertujuan untuk mengetahui fungsi setiap komponen secara keseluruhan desain yang digunakan pada penelitian ini. Hypobaric storage didesain menggunakan software Google Sketchup 2017. Rancangan hypobaric storage dapat dilihat pada Gambar 1.

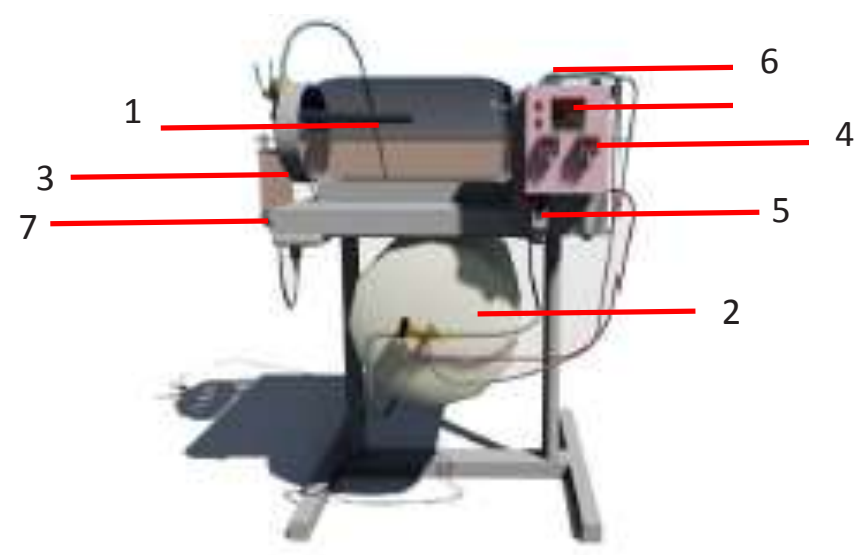

Keterangan:
1. Ruang penyimpanan
5. Relay
2. Reservoir tank
6. Switching terminal
3. Humidifier
4. Sensor suhu dan tekanan
7. Lampu halogen

Gambar 1. Rancangan hypobaric storage for chili 
Ruang penyimpanan cabai rawit terbuat dari toples kaca. Storage room yang digunakan dapat dilihat pada Gambar 2. Toples kaca yang digunakan pada alat ini adalah tabung kaca untuk makanan ringan dengan spesifikasi:
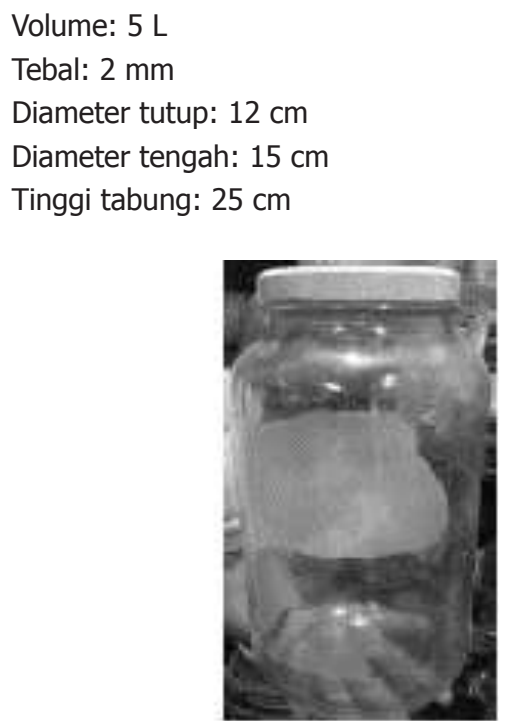

Gambar 2. Storage room

Reservoir tank merupakan komponen yang berfungsi sebagai cadangan ruang hampa. Bagian ini dibuat dengan menggunakan tabung pompa air yang memiliki kapasitas 19 L. Reservoir tank menghubungkan vacuum pump dengan ruang penyimpanan. Tujuan penggunaan komponen ini adalah meringankan kerja dari pompa vakum. Apabila tekanan udara pada ruang penyimpanan bertambah tinggi maka udara tersebut akan tervakum kedalam reservoir sehingga ruang penyimpanan terjaga dalam kondisi vakum dan pompa vakum hanya akan menyala jika reservoir tank telah terisi penuh. Reservoir tank yang digunakan dapat dilihat pada Gambar 3.

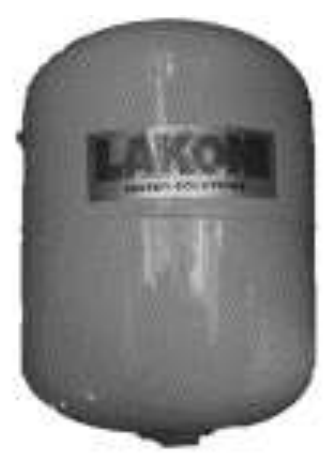

Gambar 3. Reservoir tank

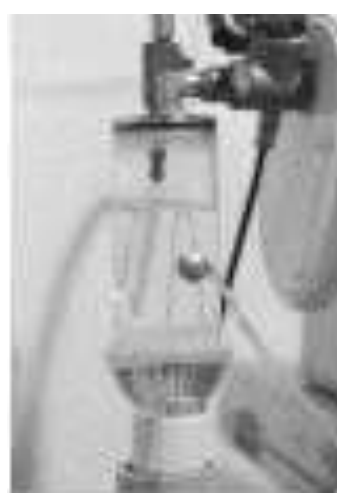

Gambar 4. Humidifier

Humidifier adalah komponen yang berfungsi menjaga suhu dan kelembaban yang terdapat dalam ruang penyimpanan. Komponen ini dibuat dengan menggunakan tabung acrylic dengan kapasitas $100 \mathrm{~mL}$. Humidifier akan bekerja secara terus menerus untuk menjaga kelembaban pada ruang penyimpanan serta suhu yang telah ditetapkan sebesar $22,9^{\circ} \mathrm{C}$. Prinsip kerja dari humidifier yaitu mengalirkan uap air dengan kelembaban tinggi kedalam ruang penyimpanan dengan menggunakan perbedaan tekanan. Humidifier yang digunakan dapat dilihat pada Gambar 4.

Sensor suhu dan tekanan digunakan untuk mengetahui suhu dan tekanan pada alat. Sensor suhu berupa thermo couple diletakkan di dalam humidifier dan dihubungkan dengan kontrol suhu. Suhu pada humidifier akan dibaca sensor suhu, kemudian akan ditampilkan pada display kontrol suhu, apabila terjadi ketidaksesuaian suhu ruangan dengan suhu optimal, maka suhu pada humidifier akan menyesuaikan. Alat ini menggunakan 2 sensor tekanan. Sensor yang pertama diletakkan pada ruang penyimpanan yang dihubungkan dengan reservoir tank. Sensor ini berfungsi membaca tekanan pada ruang penyimpanan. Sedangkan sensor kedua diletakkan pada reservoir tank yang dihubungkan dengan vacuum pump. Sensor ini berfungsi membaca tekanan dalam reservoir tank.

Relay merupakan komponen elektronik yang berfungsi untuk memutuskan dan menyambung arus dalam suatu rangkaian elektronik. Pada alat ini relay digunakan untuk memutus dan menyambungkan arus listrik pada vacuum pump, solenoid valve, dan lampu halogen. Berikut relay yang digunakan dapat dilihat pada Gambar 5 dengan spesifikasi:

Merek : Schneider Electric

Tipe : RXM2LB1BD

Amper : $5 \mathrm{~A}$

Jumlah Pin : 8

Voltase : 24VDC 


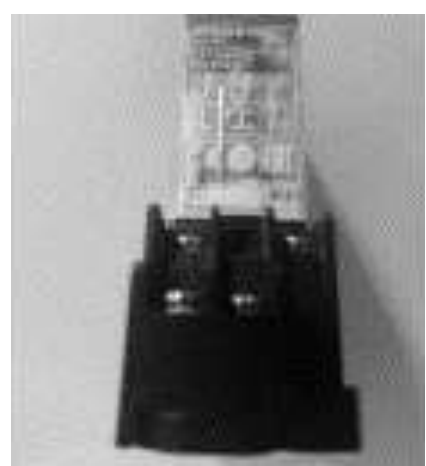

Gambar 5. Relay 24 VDC

Switching terminal berfungsi sebagai pengubah tegangan 220 Volt AC menjadi Tegangan 24 Volt DC dengan arus sebesar 2 A. Switching ini akan dihubungkan dengan setiap komponen elektronik pada alat ini untuk dapat menyalurkan arus listrik. Switching terminal yang digunakan dapat dilihat pada Gambar 6 .

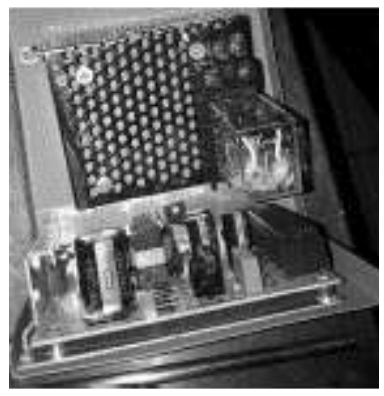

Gambar 6. Switching terminal

Lampu halogen pada alat ini berfungsi sebagai pemanas pada proses humidifikasi. Panas yang dihasilkan pada saat lampu menyala akan digunakan untuk memanaskan air pada humidifier untuk menguapkan air dengan kelembaban tinggi kedalam Storage Room. Lampu halogen yang digunakan memiliki daya sebesar 50 watt. Lampu halogen yang digunakan dapat dilihat pada Gambar 7.

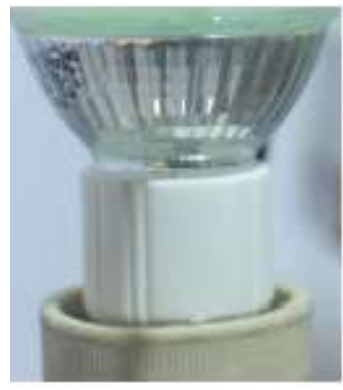

Gambar 7. Lampu halogen

\section{Pengujian Alat}

\section{Pengujian kebocoran storage room}

Pengujian kebocoran pada storage room dimaksudkan untuk memastikan tidak ada kebocoran yang terjadi pada storage room. Hal ini dilakukan untuk menghindari kegagalan sistem hypobaric apabila terjadi kebocoran. Pengujian dilakukan dengan membuat tekanan gauge pada storage room hingga mencapai -93 $\mathrm{kPa}$ dan diamati apabila terjadi pengurangan tekanan di dalamnya setiap 10 menit sekali selama 1 jam.

\section{Pengujian kebocoran reservoir tank}

Pengujian kebocoran pada reservoir tank dimaksudkan untuk memastikan tidak ada kebocoran yang terjadi pada reservoir tank. Hal ini dilakukan untuk menghindari kegagalan sistem pada reservoir tank sehingga tidak dapat menjaga tekanan pada storage room. Pengujian dilakukan dengan membuat tekanan pada reservoir tank hingga mencapai $-93 \mathrm{kPa}$ dan diamati pengurangan tekanannya setiap 1 hari sekali selama 11 hari.

\section{Pengujian vacuum pump}

Pengujian performansi vacuum pump dilakukan untuk mengetahui seberapa cepat proses pemvakuman yang terjadi menggunakan pompa vakum $1 / 4 \mathrm{hp}$. Pengujian dilakukan pada bagian Storage room dan reservoir tank. Hal ini dimaksudkan agar mengetahui apakah kapasitas pompa yang digunakan sudah mencukupi atau belum. Pengujian dilakukan dengan memvakum udara pada storage room dan reservoir tank hingga mencapai $80 \mathrm{kPa}$ dan dilihat berapa lama waktu yang diperlukan untuk mencapai tekanan tersebut.

\section{Pengujian Kimiawi pada Cabai Rawit}

\section{Pengujian susut bobot}

Pengujian susut bobot dilakukan dengan melakukan penimbangan terhadap $30 \mathrm{~g}$ cabai rawit. Kemudian dilakukan pengulangan proses penimbangan terhadap sampel setiap dua hari sekali. Hasil penimbangan diolah untuk mendapatkan nilai susut bobot dengan Persamaan 1 menurut Gayathri dkk. (2016).

$\%$ Susut Bobot $=\frac{W 0-W 1}{W 0} \times 100 \%$

W0 = Berat bahan hari ke-0

W1 = Berat bahan hari ke-1 


\section{Pengujian kadar air}

Pengujian kadar air dilakukan untuk mengetahui banyaknya air yang terkandung pada bahan. Pengujian dilakukan dengan menggunakan moisture analyzer AND Weighing model MX50 dengan menggunakan sampel sebanyak $3 \mathrm{~g}$. Hasil yang ditunjukan oleh alat ini langsung berupa persentase nilai kadar air bahan yang diujikan.

\section{Pengujian vitamin C}

Pengujian vitamin $\mathrm{C}$ dilakukan untuk mengetahui kandungan vitamin $\mathrm{C}$ yang terdapat pada cabai rawit setelah penyimpanan dengan hypobaric storage. Pengujian vitamin $\mathrm{C}$ dilakukan dengan metode titrasi iodimetri. Perhitungan kadar vitamin C menurut Sudarmadji (2003) (Persamaan 2).

Mg vitamin C / $100 \mathrm{~g}=\frac{\text { Volume iodin } \times 0.88 \times \mathrm{FP} \times 100}{W}$

Dimana FP merupakan faktor pengali dan W merupakan berat bahan.

\section{HASIL DAN PEMBAHASAN}

\section{Pendesainan Alat}

Desain hypobaric storage mengacu pada hasil studi pustaka yang menggunakan tekanan dan suhu rendah, serta kelembaban tinggi. Prinsip kerja hypobaric adalah ketika udara masuk dan keluar sistem melewati saluran udara dan diatur tekanannya dengan regulator tekanan. Adanya pertukaran udara ini berfungsi untuk menyeimbangkan dan mengurangi tekanan dalam ruang penyimpan. Kemudian, air masuk kedalam humidifier dan menaikkan kelembaban udara menjadi $80-100 \%$. Air suling yang berasal dari reservoir, air ditambahkan

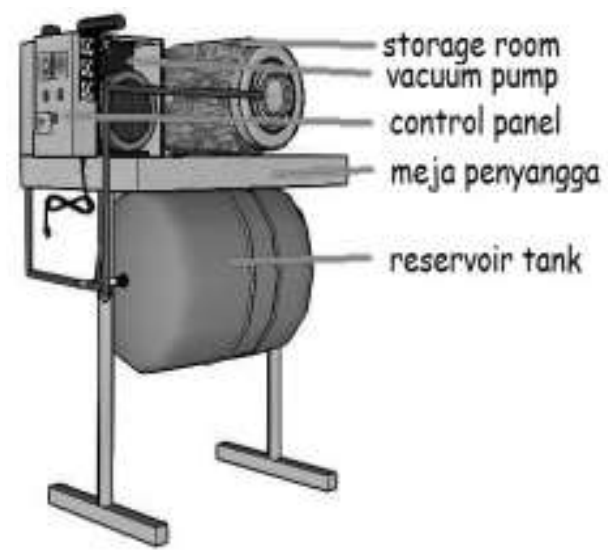

Gambar 8. Desain hypobaric storage tampak samping

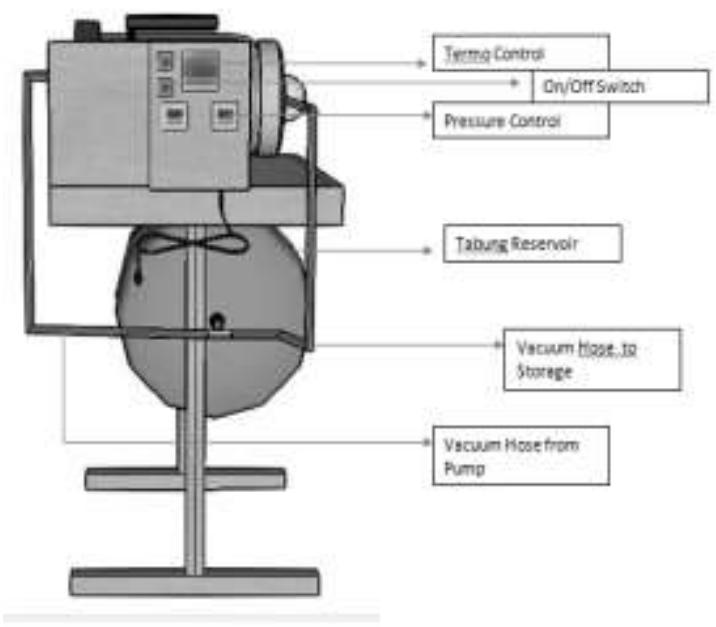

Gambar 9. Desain hypobaric storage tampak samping

secara periodik kedalam humidifier. Sistem humiditifikasi ini bertujuan untuk menghilangkan panas yang diterima oleh lingkungan untuk mencegah kehilangan air dengan cara memberikan uap air dengan kelembaban tinggi didalam ruang penyimpanan. Kemudian, air jenuh akan dikirim ke tangki vakum penyimpanan melalui saluran air. Komoditas pangan disimpan dalam tangki dalam kondisi vakum (Goyal dan Sivanappan, 2017). Rancangan hypobaric storage dapat dilihat pada Gambar 8 dan 9.

\section{Perakitan Alat}

Perakitan dibagi menjadi 7 kegiatan, yaitu pembuatan storage room, pembuatan reservoir tank, pembuatan humidifier, pemasangan sensor suhu dan tekanan, pembuatan control panel, dan pemasangan pada komponen pendukung. Storage room dibuat dari tabung kaca tertutup berkapasitas $300 \mathrm{~g}$. Bagian ini dilengkapi dengan rak untuk memudahkan penyimpanan cabai rawit. Reservoir tank dibuat dari tangki air berbentuk tabung yang memiliki kapasitas 19 L. Bagian ini dihubungkan dengan vacuum pump dan storage room. Humidifier dibuat dari bahan kaca yang berbentuk tabung dengan panjang $10 \mathrm{~cm}$ dan berdiameter $3 \mathrm{~cm}$ yang memiliki kapasitas $100 \mathrm{~mL}$ air. Mesin ini menggunakan 3 sensor,yaitu 1 sensor suhu dan 2 sensor tekanan. Pemasangan sensor suhu dilakukan pada storage room, sedangkan sensor tekanan dipasang pada storage room dan reservoir tank. Control panel yang dibuat terdiri dari tombol power suhu,tombol power tekanan, display suhu, dan 2 display tekanan. Pembuatan komponen pendukung yang berupa meja penopang, dimana meja ini memiliki ukuran $45 \times 30 \times 60$ $\mathrm{cm}$ dan terbuat dari stainless steel. Komponen mesin dikelompokan dan terdiri dari storage room, reservoir tank, vacuum pump, humidifier, control panel disusun 


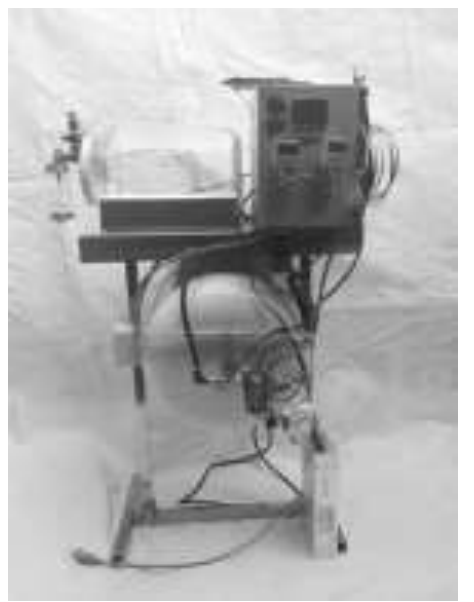

Gambar 10. Penampakan hypobaric storage tampak depan

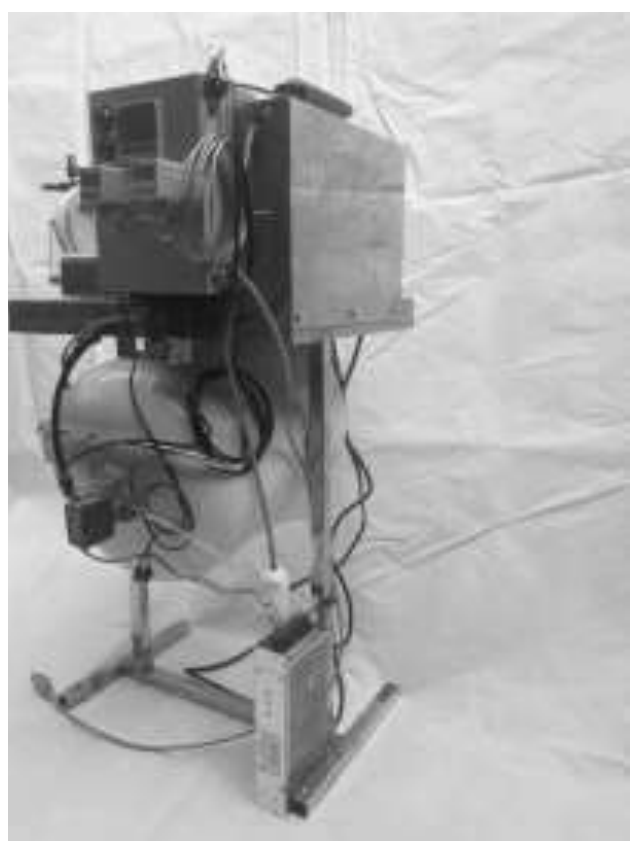

Gambar 11. Penampakan hypobaric storage tampak samping pada meja penopang. hypobaric storage yang telah dirakit dapat dilihat pada Gambar 10 dan 11.

\section{Pengujian Performansi Mesin}

Pengujian performansi yang telah dilakukan adalah uji kebocoran tekanan reservoir tank, uji kebocoran tekanan storage room, uji relay (otomatisasi sensor tekanan) dan uji pompa vakum. Uji kebocoran tekanan dan uji relay dilakukan sebelum alat dirakit, sedangkan uji pompa vakum dilakukan setelah komponen dirakit.

\section{Pengujian kebocoran tekanan storage room}

Pengujian kebocoran pada storage room dilakukan untuk memastikan tidak ada kebocoran pada ruang penyimpanan sehingga tekanan ruang penyimpanan dapat terjaga. Pengujian ini dilakukan dengan cara membuat keadaan dalam ruang penyimpanan menjadi vakum pada tekanan gauge sebesar -93.3 kPa dan diamati selama 60 menit. Data kebocoran diambil sebanyak enam kali dengan jarak setiap pengamatan adalah 10 menit. Berikut adalah grafik uji kebocoran pada storage room dapat dilihat pada Gambar 12.

Grafik tersebut menunjukkan bahwa tekanan yang berada di dalam tabung relatif konstan, hanya terdapat perubahan yang tidak signifikan di menit awal. Hal ini menunjukkan bahwa toples kaca sebagai wadah penyimpanan dapat menjaga tekanan yang telah diatur secara stabil. Kesimpulan yang dapat diambil bahwa toples kaca tersebut layak untuk digunakan sebagai ruang penyimpanan hypobaric.

\section{Pengujian kebocoran tekanan reservoir tank}

Dalam alat hypobaric storage, reservoir tank berfungsi sebagai tempat cadangan ruang hampa untuk meringankan kerja dari vacuum pump agar tidak terus menyala selama pengoperasian alat. Pengujian kebocoran dilakukan dengan membuat reservoir tank

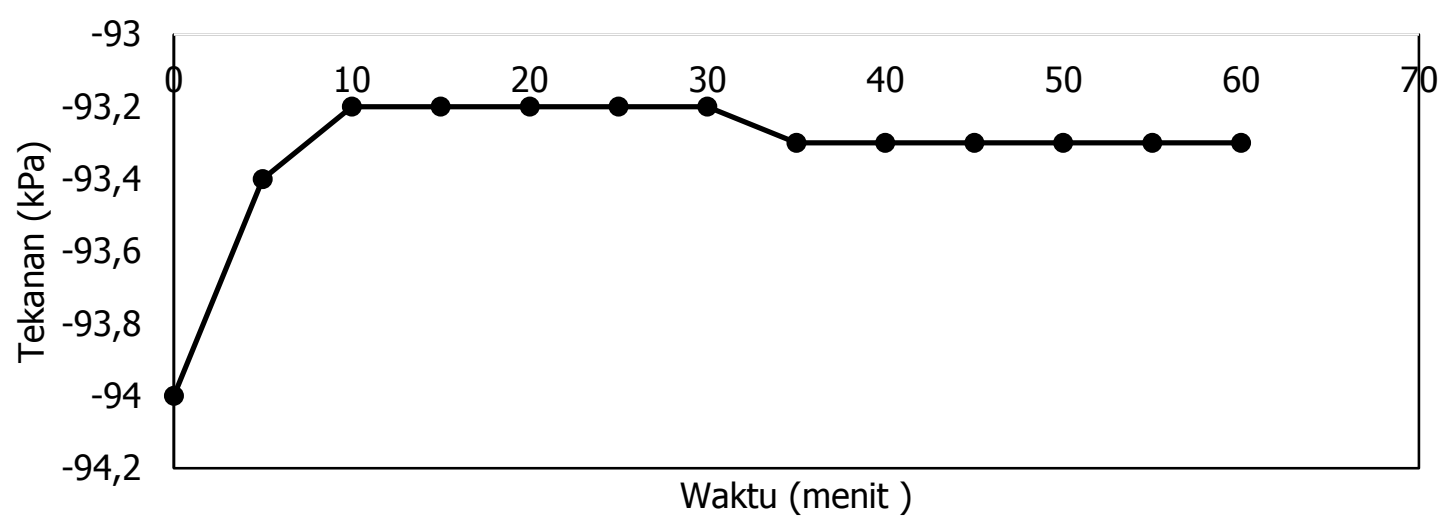

Gambar 12. Grafik uji kebocoran tekanan storage room 
D.M. Maharani dkk. /Agritech 30 (2) 2019 143-152

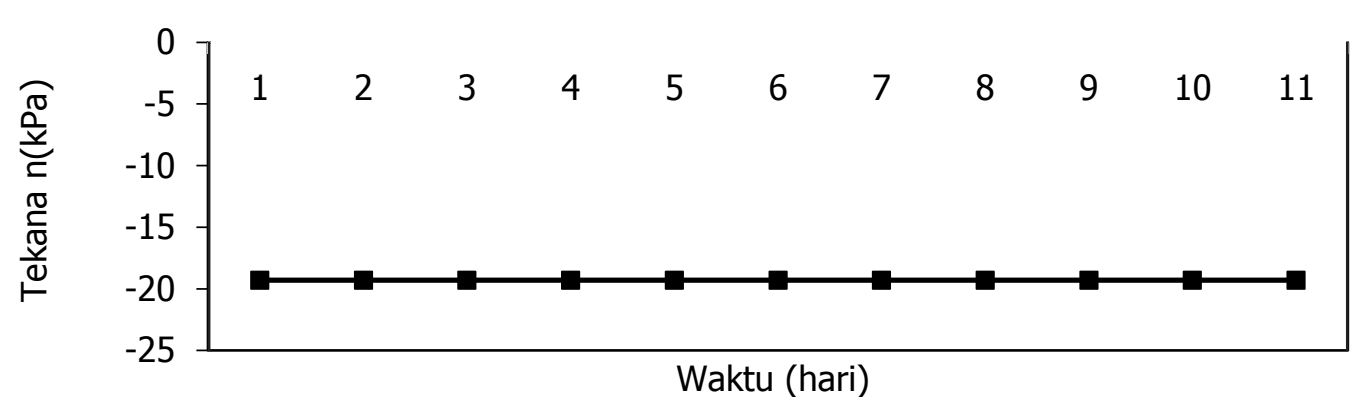

Gambar 13. Grafik uji kebocoran tekanan reservoir tank

dalam keadaan vakum pada tekanan -93.3 kPa dan dibiarkan dalam keadaan rapat. Pengamatan kebocoran pada reservoir tank dilakukan lebih lama yaitu selama 6 jam dan dicatat perubahannya setiap satu jam sekali. Grafik hasil uji kebocoran pada reservoir tank dapat dilihat pada Gambar 13.

Pada grafik dapat dilihat bahwa nilai tekanan pada reservoir tank yang menggunakan tabung pompa berkapasitas $19 \mathrm{~L}$ relatif konstan. Hal ini menunjukkan bahwa reservoir tank dapat menjaga tekanan yang telah diatur secara stabil. Sehingga dapat disimpulkan bahwa reservoir tank dapat digunakan sebagai cadangan udara vakum untuk meringankan kerja pompa vakum dari alat ini. Dengan penggunaan reservoir tank pada hypobaric storage dapat membuat pompa menyala hanya setiap 5 sampai 10 menit sekali. Sehingga pompa vakum tidak menyala terus menerus dan dapat menghemat penggunaan energi untuk menjalankan pompa vakum.

\section{Pengujian relay}

Pengaturan otomatisasi dikendalikan melalui relay untuk memastikan bekerja atau tidaknya vacuum pump sebagai komponen utama dalam menciptakan ruang penyimpanan hypobaric. Untuk pengaturan tekanan dilakukan dengan menggunakan modul pressure control SMC ZSE-40. Pada modul ini besaran tekanan yang ditunjukan adalah $\mathrm{kPa}$. Sistem otomatisasi pada modul tekanan tersebut yang diambil dari manual 43 book SMC ZSE-40 dapat dilihat pada Gambar 14.

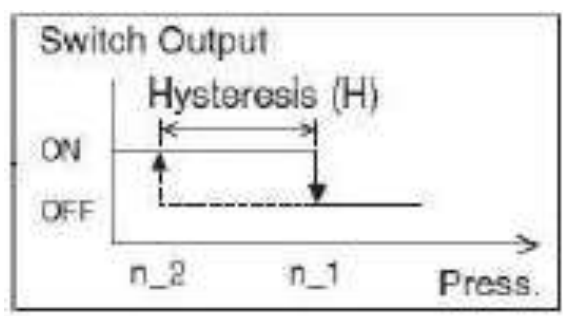

Gambar 14. Sistem otomatisasi
Bagian hysteresis yang merupakan titik dimana sistem tidak akan berfungsi maka arus listrik akan diputus sehingga pompa tidak bekerja, sedangkan diluar dari rentan besaran hysteresis maka pompa akan kembali bekerja untuk mendapatkan tekanan yang diatur pada sistem tersebut. Untuk hasil pengujian relay dapat dilihat pada Tabel 2 .

Tabel 2. Hasil pengujian relay

\begin{tabular}{ccc}
\hline No. & Tekanan $(\mathrm{kPa})$ & Lampu \\
\hline 1 & $\geq-50$ & Nyala \\
2 & $-51-(-54)$ & Nyala \\
6 & $\leq-55$ & Mati \\
\hline
\end{tabular}

Hal ini ditunjukkan dengan indikator lampu yang menyala dari kondisi tekanan $\geq-50 \mathrm{kPa}$ hingga -55 $\mathrm{kPa}$ yang menandakan adanya arus untuk menyalakan pompa, dan indikator lampu mati pada tekanan $\leq-56$ $\mathrm{kPa}$ yang menandakan arus listrik diputus sehingga pompa berhenti bekerja.

\section{Pengujian pompa vakum}

Pengujian kinerja vacuum pump dilakukan untuk menguji seberapa lama pompa vakum dapat membuat tekanan pada ruang penyimpanan sesuai dengan pengaturan. Berdasarkan data yang didapatkan pada pengujian kebocoran tekanan maka tekanan pada reservoir tank dapat bertahan pada rentan waktu 5 sampai 10 menit. Sedangkan pada storage room tekanan mampu bertahan sekitar 1 menit, hal ini dikarenakan adanya humidifier pada storage room. Hasil pengujian kinerja pompa vakum yang diuji pada storage room dan reservoir tank dapat dilihat pada Tabel 3. 
Tabel 3. Hasil pengujian panel tekanan pada storage room dan reservoir tank

\begin{tabular}{cccc}
\hline $\begin{array}{c}\text { Perlakuan } \\
\text { ke- }\end{array}$ & $\begin{array}{c}\text { Tekanan } \\
(\mathrm{kPa})\end{array}$ & \multicolumn{2}{c}{$\begin{array}{c}\text { Waktu yang dibutuhkan } \\
\text { (menit) }\end{array}$} \\
\cline { 3 - 4 } & & Storage room & $\begin{array}{c}\text { Reservoir } \\
\text { tank }\end{array}$ \\
\hline 1 & -30 & 8 & 23 \\
2 & -60 & 19 & 68 \\
3 & -90 & 29 & 95 \\
\hline
\end{tabular}

\section{Efisiensi Mesin}

Pengujian ini bertujuan untuk mengetahui keseimbangan energi input dan output yang digunakan pada alat. Energi input yang digunakan alat adalah 378 $\mathrm{kkal} / \mathrm{jamdengan}$ energi output sebesar 309,54 kkal/jam, sehingga didapatkan efisiensi mesin hypobaric storage sebesar $81,82 \%$. Perhitungan efisiensi mesin tersaji pada Persamaan 3-5.

Diketahui:

$$
\begin{aligned}
& E \text { input }=V \text { input } \times I \text { input } \\
& E \text { input }=220 \text { Volt } \times 2 \mathrm{~A} \\
& E \text { input }=400 \text { watt } \\
& E \text { input }=378,33 \text { kkal/jam } \\
& E \text { output }=\text { Jumlah daya tiap-tiap komponen } \\
& E \text { output }=P \text { vacuum pump }+ \\
& (P \text { heater }+P \text { control panel }) \\
& \text { E output }=300 \text { watt }+60 \text { watt } \\
& E \text { output }=360 \text { watt } \\
& \text { E output }=309,54 \mathrm{kkal} / \text { jam } \\
& \text { Efisiensi mesin: } \\
& \text { Efisiensi }=(E \text { output } / \mathrm{E} \text { input }) \times 100 \% \\
& \text { Efisiensi }=(309,54 / 378,33) \times 100 \% \\
& \text { Efisiensi }=81,82 \%
\end{aligned}
$$

\section{Pengujian Kimiawi pada Cabai Rawit}

Pengujian ini berfungsi untuk mengetahui tingkat keefektifan hypobaric storage. Bahan yang digunakan dalam uji adalah cabai rawit yang bewarna oren kemerahan. Perlakuan diberikan dengan tekanan optimal sesuai dengan penelitian yaitu -60 hingga -55 $\mathrm{kPa}$, dengan suhu $22,9^{\circ} \mathrm{C}$ dan pengamatan dilakukan setiap 24 jam.

Pengujian berupa kadar vitamin C susut bobot dan kadar air dilakukan selama 14 hari penyimpanan. Pengujian dilakukan dengan membandingkan laju perubahan per hari dengan 3 perlakuan penyimpanan yaitu suhu ruang, refrigerator, dan Hypobaric storage. Pengujian parameter pada hari ke-0 dapat dilihat pada Tabel 4. Perbandingan persentase perubahan kadar vitamin $\mathrm{C}$ susut bobot dan kadar air dapat dilihat pada
Tabel 5. Berdasarkan hasil tersebut disimpulkan bahwa hypobaric storage mampu mempertahankan parameter kualitas yang lebih baik disbanding perlakuan lainnya.

Tabel 4. Pengujian parameter cabai rawit pada hari ke-0

\begin{tabular}{llll}
\hline Parameter & \multicolumn{3}{c}{ Metode penyimpanan } \\
\cline { 2 - 4 } & Suhu ruang & Refrigerator & $\begin{array}{c}\text { Hypobaric } \\
\text { storage }\end{array}$ \\
\hline Susut bobot (g) & 60 & 60 & 60 \\
Vitamin C & 202,4 & 222,64 & 212,2 \\
(mg/100 g) & & & \\
Kadar air (\%) & 78,42 & 75,63 & 78,35 \\
\hline
\end{tabular}

Tabel 5. Perubahan kualitas kimiawi cabai rawit

\begin{tabular}{llll}
\hline & \multicolumn{3}{c}{ Metode penyimpanan } \\
\cline { 2 - 4 } Parameter & Suhu ruang & Refrigerator & $\begin{array}{c}\text { Hypobaric } \\
\text { storage }\end{array}$ \\
\hline $\begin{array}{l}\text { Susut bobot } \\
\begin{array}{l}\text { Penurunan } \\
\text { vitamin C }\end{array}\end{array}$ & $9,7 \%$ & $6,66 \%$ & $3,28 \%$ \\
$\begin{array}{l}\text { Penurunan } \\
\text { kadar air }\end{array}$ & $15,98 \%$ & $68,61 \%$ & $12,91 \%$ \\
\hline
\end{tabular}

\section{KESIMPULAN}

Berdasarkan hasil pengujian dan penelitian yang dilakukan pada hypobaric storage yang digunakan sebagai alat penyimpanan cabai rawit maka dapat disimpulkan bahwa hypobaric storage terdiri dari toples kaca sebagai storage room, humidifier, humidifier, vacuum pump, dan reservoir tank. Kapasitas dari ruang penyimpanan ini mencapai $500 \mathrm{~g}$ cabai rawit. Otomatisasi komponen elektronik pada control panel berjalan dengan baik sehingga mampu mempertahankan keaadan hypobaric pada ruang penyimpanan. Hasil dari pengujian kebocoran pada ruang penyimpanan tidak menunjukkan adanya kebocoran. Selama satu bulan pengoperasian semua komponen elektronik dan sistem otomatisasi pada hypobaric storage dapat berfungsi dengan baik untuk mempertahankan ruang penyimpanan dalam kondisi vakum pada tekanan 50 sampai $-60 \mathrm{kPa}$. Cabai rawit yang disimpan pada hypobaric storage memiliki susut bobot, penurunan kadar air, dan penurunan vitamin $\mathrm{C}$ lebih kecil.

\section{UCAPAN TERIMA KASIH}

Terima kasih kami ucapkan kepada Allah SWT yang senantiasa melimpahkan karuniannya sehingga 
kami dapat menyelesaikan jurnal ini, serta kepada KEMENRISTEK DIKTI yang telah memberikan dana sehingga program ini berjalan lancar.

\section{KONFLIK KEPENTINGAN}

Penulis menyatakan bahwa artikel ini asli, belum pernah dipublikasikan, dan bebas dari konflik kepentingan.

\section{DAFTAR PUSTAKA}

Arifin \& Ihsanul. (2010). Pengaruh cara dan lama penyimpanan terhadap mutu cabai rawit (Capsicum frutencens $L$ var. cengek). Malang: Universitas Islam Negeri Maulana Malik Ibrahim.

Asgar, A., Darkam, M., \& Rahmat, S. (2017). Pengaruh ozonisasi dan kemasan untuk mereduksi residu pestisida dan mempertahankan karakteristik kesegaran cabai merah dalam penyimpanan. Jurnal Hort, 27(2), 241 -252.

Asgar, A., Musaddad, D., Setyabudi, D. A., \& Hassan, Z. H. (2015). Teknologi Ozonisasi untuk Mempertahankan Kesegaran Cabai Cultivar Kencana Selama Penyimpanan. J. Penelitian Pascapanen Pertanian, 12(1), 20-26.

Cantwel, M. (2009). Recommendations for Maintaining Postharvest Quality. Davis: Postharvest Technology University of California.

Chen, H., Yang, H., Gao, H., Long, J., Tao, F., Fang, X., \& Jiang, Y. (2013). Effect of Hypobaric storage on Quality, Antioxidant Enzyme and Antioxidant Capability of the Chinese Bayberry Fruits. Chemistry Central Journal. 7(4), 1-7.

Chitravathi, K., Chauhan, O. P., \& Raju, P. S. (2016). Shelf Life Extension of Green Chillies (Capsicum annuum L.) Using Shellac-Based Surface Coating in Combination with Modified Atmosphere Packaging. Journal Food Science Technology, 53(8), 3320-3328.

Farid, M. \& Subekti, N. A. (2012). Tinjauan terhadap Produksi, Konsumsi, Distribusi, dan Dinamika Harga Cabe di Indonesia. Buletin I/miah Perdagangan, 6(2), 211-233.

Gayathri, V., Shruthy, R. K., \& Shiburaj, S. (2016). Purification and Characterization of Carboxymethyl Cellulase (CMCase) from Penicillium ochrochloron isolated from Forest Soil of Neyyar Wild Life Sanctuary, India. International Journal of Biotechnology and Biochemistry, (12), $131-144$.
Goyal, M. R., \& Sivanappan, K. (2017). Engineering Practices for Agricultural Production and

Water Conservation: An Interdisciplinary Approach. New York: CRC Press

Hameed, R., Malik. A. U., Khan, A. S., \& Imran, M. (2015). Evaluating the Effect of Different Storage Conditions on Quality of Green Chillies (Capsicum annuum L.). Tropical Agricultural Research, 24(4), 391-399.

Pangidoan, S., Sutrisno, \& Purwanto, Y. A. (2013). Simulasi Transportasi dengan Pengemasan untuk Cabai Merah Keriting Segar. JTEP ISSN 2338-8439 Vol. 27 April 2013.

Pradita, N. (2012). Perubahan kimia dan Umur Simpan Cabai Merah (Capsicum Annum Var.Longum) dalam Penyimpanan Dinamis Udara-CO2. Bandar Lampung: Universitas Lampung.

Purwadaria, H. K. (1992). Sistem Pengangkutan Buah-buahan dan Sayuran. PAU Pangan dan Gizi: Bogor.

Rochayat, Y. \& Munika, V. R. (2015). Respon Kualitas dan Ketahanan Simpan Cabai Merah (Capsicum annuum L.) dengan Penggunaan Jenis Bahan Pengemas dan Tingkat Kematangan Buah. Jurnal Kultivasi, 14(1), 65-71.

Saraswati, I. G. A. E., Pharmawati, M., \& Junitha, I. K. (2012). Karakter Morfologi Tanaman Cabai Rawit (Capsicum frustescens L.) yang Dipengaruhi Sodium Azida pada Fase Generasi M1. Jurnal Biologi, 16(1), 23-26.

Sudarmadji, S., Bambang, H., \& Suhardi. (2003). Analisis Bahan Makanan dan Pertanian. Yogyakarta : Liberty.

Thompson, A. K. (2016). Fruit and Vegetable Storage: Hypobaric, Hyperbaric and Controlled Atmosphere. London: Springer.

Umam, K. (2017). Respon Kualitas Cabai Rawit Merah (Capsicum frutescens L.) terhadap Suhu Penyimpanan. Bogor: Institut Pertanian Bogor

Zapotoczny, P., \& Markowski, M. (2014). Influence of Hypobaric storage on the Quality of Greenhouse Cucumbers. Bulgarian Journal of Agricultural Science, 20(6), 14061412. 